American J. of Engineering and Applied Sciences 4 (2): 307-313, 2011

ISSN 1941-7020

(C) 2011 Science Publications

\title{
Towards more Manageable Coastal Building; Initial Coastal Building Construction Guidelines
}

\author{
${ }^{1}$ Roslan Talib and ${ }^{2}$ Mohd Z. Sulieman \\ ${ }^{1}$ Department of Interior Design, School of Housing, \\ ${ }^{2}$ Department of Building Technology, School of Housing, \\ Building and Planning, University Sains, Malaysia
}

\begin{abstract}
Problem statement: As we may not be aware that the coastal construction is different from inland construction. Building in a coastal environment is different from building in an inland area. In general, buildings in coastal areas must be designed and built to withstand higher loads due to its more extreme conditions. Nowadays, the issue of global warming, uncertainty of global weather and the climate change effect indirectly creating the coastal area with much more expose to extreme condition. Formulate initial guidelines with certain degree of details how coastal construction requirements are different from those for inland construction. Approach: Due to the exposure to higher loads and extreme conditions, these structures in coastal areas will cost more to design, construct, maintain, repair and insure. Proper and right usage of building materials including electrical and mechanical equipments, are crucial in order to minimize damage. Nowadays, the issue of global warming, uncertainty of global weather and the climate change effect indirectly creating the coastal area with much more expose to extreme condition. Feedback has been gathered from the government local engineers who are doing the management of the Government's local buildings located along the coastal area of Peninsular Malaysia. Data findings through research method, discussion with the suppliers and discussion with coastal buildings maintenance crews also has been done. Results: The research finding discus the specific characteristics that makes for successful coastal buildings focusing in tropical region. Conclusion: We must accept on the idea of building in coastal areas will require more maintenance and upkeep. By having proper coastal building guideline may create more positive awareness in constructing better management coastal buildings and can save time and money to maintain the said structures.
\end{abstract}

Key words: Coastal construction, coastal environment, coastal buildings, building maintenance, extreme conditions, tropical region, site planning, building design, construction material

\section{INTRODUCTION}

This initial guideline for the coastal buildings is based on the report prepared based on a detail correspondence research done earlier. The objectives of this guideline are:

- As a reference when making alteration on the existing standard building plans that will be build along the coastal area

- As a reference when preparing new buildings plan located next to the sea

- As a reference for the Site Officer oversee the ongoing coastal buildings construction

- As a guide during maintenance and renovation works on existing coastal buildings
The method of study focuses on:

- To get feedback regarding coastal building maintenance problems from the Public Work Department's State Engineers.

- To visit identified problematic coastal buildings.

- Data findings through research method, discussion with the suppliers and discussion with coastal buildings maintenance crews.

Research findings: The research finding is the study work which has been divided into 4 main topics:

- Site planning

- Building design

- Detail design

- Construction material

Corresponding Author: Roslan Talib, Department of Interior Design, School of Housing, Building and Planning, University Sains, Malaysia 
Site planning: When doing the site planning for certain kind of coastal project, several certain aspects of early planning must be considered. This early planning can determine the lasting performance of the building materials and thus can projected higher or lower maintenance cost of that particular building. For example, for comparison; the development occurred in the coastal area in country where abound of water surround like Greece (in this case the Faliraki coastal area) have great potential for hotel development and a big tourist movement. The research report indicated that the more intense usage of the coastal land; the more environmental destruction impacting the area (Economou, 2009).

At the time, it seems like the building developer are also keen to build along the hilly terrain to gain better view for market purposes other than the coastal area. However, building structure over the hilly terrain like Penang Island in Malaysia as a good example; facing much greater potential of landslip problems thus looking back having coastal development are more preferable geologically (Ahmad et al., 2006).

\section{MATERIALS AND METHODS}

This aspect of initial planning is discus under 2 building categories which are Air-Conditioned Building and non air-conditioned building.

Air-conditioned building: For building under this category, resulted and exposed to coastal phenomena only emphasized on the external enclosure only.

- Building under this category can be built within the beach area if the materials for the building's external enclosure are made from those in Table 5. The materials use for the building interior for this building category is not that critical since they are always enclosed

- By having the buffer element i.e. tress or vegetation or holding structure can reduce the extreme exposure of the coastal phenomena

- For building under this category, building orientation is not that critical if the right steps have been taken to suite the right building materials

Note: The drop of building internal air temperature on every 18 degree Fahrenheit, can reduce the rusting process up to half (Gleekman L.W, Materials and Corrosion Engineering Services, Southfield, Mich).

Non air-conditioned building: For building under this category, ventilation comes from cross ventilation of the coastal salty air. Meaning that this building has been exposed to the hostility coastal phenomena as a whole; including the building interior fittings.

Building under this category is not encouraged to be built too close to the coast/beach. More appropriate site can be at the cove area or a lagoon or behind the coastal hill where sea breeze not directly exposed:

- Having buffer element can help to reduce the bad impact due to the coastal phenomena

- Avoid on having maximum façade openings toward sea air flow

- In the event of the building being built with commercial implication, if the sea-view orientation is very critical; please ensure right and quality performance materials being used

For both building categories, opinion from other Government departments i.e., Department of Irrigation, Oceanic Department and local knowledge must be considered while doing the layout planning. If the project location turns out to be not safe, please ensure this information must be made known to the client.

Building design: During the building design stage, the followings are to be considered:

- Avoid using complex structural design as it can lead to inaccuracy of structural construction. When this happen, rain water with strong wind can penetrate into the building structure thus can destroy it. As a result the building structure can fail

- For 2 storey building or low rise, avoid using complex and tiny internal gutter. Gutter like this always collected dried leaves and light garbage flown by strong sea wind thus cut-out the rain water flow to down-pipe

- Items and interior fittings which are made from metal must not directly located along the sea air flow to avoid or to slow-down the unusable process of the fittings

- Building with Mechanical and Electrical Fitting Room (Mechanical Plant Room), Electrical Distributor (Generator Room) and water tank must be located at the farther position from the beach with location at the back of the building in order not to have direct exposure to sea air. The fitting space must be always enclosed (air-tight)

- Verandah next to the building must be widen and protected with extended roof line to avoid rainwater seepage coming from strong wind

- Electrical and Mechanical fittings i.e., Distribution Board or Switch Board must not be located at the 
exposed area like office wall, corridor and hospital ward. Electrical and Mechanical Service Room must be positioned in such a way to protect the fittings from the exposed sea air

- Building with sloping roof, must ensure enough degree of the sloping roof to take account on building position in order to maximize air speed on the area ( refer to the Meteorological Department for local air speed details data)

Note: Research reported that the storm wave is one of the premier causes of the shoreline erosion and disaster. The storm wave height and the storm wave energy giving greater impact to coastal development and should also be studied. The effects of storm wave and the shoreline erosion must be simulated under the storm wave height and erosion parameters and impacting coastal structures (Ekphisutsuntorn et al., 2010). Thus, the mechanisms of the erosion and other factors must be considered for the Peninsular Malaysia shorelines development and other shorelines which have the storm wave effects. The suitable solves and suitable protections can be considered in the future.

Detailed design: In detailed design preparation stage, one building must take the following accounts:

- All heavy equipments i.e., classroom white board, wash basin must have base supporting structure; not top-hanging type due to the top-hanging type having nail or metal screw expose to rust which can lead to lose without warning

- Where ever there are windows, window with casement type is much more appropriate than louvers one

- For interior blockade, avoid using folding partition type as the hinge can be easily rusty thus resulted the partition is not proper and practical usage purpose

- In designing metal roofing decking, attention must be given to the jointing system. Use the non-direct exposure system in which no nail been used and expose to the weather

- In timber works, traditional construction using tongue and groove (not using nail) more appropriate

- Avoid using the design of G.I. vertical Rain-WaterDownpipe (RWDP) set-in type or concealed type into the column. When rusting problem occurs, this will raised problematic maintenance

- In fixed glass ram window design, minimum angle for the glass must be at 60 degree, sloped-window sill and ensure sill accompanied with slot

- For casement window design or sliding one, use heavier glass or thicker glass to get rid of vibration due to strong sea wind
- Avoid using conventional sewerage tank i.e., filter bed to avoid backflow during high-tide. Use other systems on market with mechanical features

- For internal and external fittings, do not place them within the damp area including damp earth. Porous materials must be waterproof

- Even though detail specification and appropriate building materials been used; the construction

- quality always to be based on well-off and good supervision by Site Officer

\section{RESULTS AND DISCUSSION}

\section{Building material: \\ Roof:}

- In using metal decking, attention must be given to material quality i.e., gauge, coating type and installation technique. Always refer to the supplier for correct information according to the site (Table 1-19).

Table 1: Roofing

\begin{tabular}{llll}
\hline & Pitch roof & Flat roof \\
Metal & Asbestos & Traditional & $\begin{array}{l}\text { Metal deck } \\
\text { Zink }+\end{array}$ \\
Deck & Roof & Roof & aluminum \\
\hline zinc + aluminum & asbestos & concrete roof tile & + silicon \\
\hline 3 & 1 & 2 & 2 \\
\hline
\end{tabular}

Table 2: Rain Water Down Pipe (RWDP)

\begin{tabular}{llll}
\hline $\begin{array}{l}\text { Design type: } \\
\text { 'Set-in' }\end{array}$ & & $\begin{array}{l}\text { Design type: } \\
\text { Expose }\end{array}$ \\
\hline G.I & uPVC & G.I & uPVC \\
(Galvanized Iron) & 3 & 2 & 3 \\
1 & 3 & & \\
\hline
\end{tabular}

Table 3: Ceiling External

\begin{tabular}{llll}
$\begin{array}{l}\text { Timber } \\
\text { Strips }\end{array}$ & $\begin{array}{l}\text { Aluminum slats } \\
\text { (without spacing) }\end{array}$ & Cemboard & $\begin{array}{l}\text { Fiber } \\
\text { cement board }\end{array}$ \\
\hline 1 & 3 & 3 & 3 \\
\hline
\end{tabular}

Table 4: Interior

\begin{tabular}{|c|c|c|c|c|}
\hline \multicolumn{3}{|c|}{ Non air-conditioned } & \multicolumn{2}{|c|}{ Air-conditioned } \\
\hline $\begin{array}{l}\text { Mineral } \\
\text { fiber } \\
\text { board }\end{array}$ & $\begin{array}{l}\text { Gypsum } \\
\text { plaster } \\
\text { board }\end{array}$ & Cemboard & $\begin{array}{l}\text { Mineral } \\
\text { fiber } \\
\text { board }\end{array}$ & $\begin{array}{l}\text { Gypsum } \\
\text { plaster } \\
\text { board Cemboard }\end{array}$ \\
\hline 2 & 3 & 3 & 3 & 3 \\
\hline
\end{tabular}

Table 5: External wall finishes

Bricks/Concrete

Plaster + Shanghai $\quad$ Plaster +

Timber/board Varnish /Standard Waterproof plaster/ acrylic

Normal set shellac plaster material bonn tile Tile emulsion paint

\begin{tabular}{lllllll}
\hline 2 & 2 & 2 & 2 & 3 & 3 & 2 \\
\hline
\end{tabular}


Am. J. Eng. \& Applied Sci., 4 (2): 307-313, 2011

Table 6: Window

\begin{tabular}{|c|c|c|c|c|c|c|c|}
\hline \multicolumn{2}{|c|}{ Adjustable glass ram } & \multicolumn{2}{|c|}{ Casement } & \multicolumn{2}{|l|}{ Sliding } & \multicolumn{2}{|c|}{ Top -Hung } \\
\hline $\begin{array}{l}\text { Galvanized } \\
\text { Aluminum steel }\end{array}$ & $\begin{array}{l}\text { Anodized } \\
\text { with nylon } \\
\text { Clip }\end{array}$ & $\begin{array}{l}\text { Timber } \\
\text { frame }\end{array}$ & $\begin{array}{l}\text { Aluminum } \\
\text { frame }\end{array}$ & $\begin{array}{l}\text { Timber } \\
\text { frame }\end{array}$ & $\begin{array}{l}\text { Aluminum } \\
\text { frame }\end{array}$ & $\begin{array}{l}\text { Timber } \\
\text { frame }\end{array}$ & $\begin{array}{l}\text { Aluminum } \\
\text { frame }\end{array}$ \\
\hline 1 & 3 & 2 & 3 & 1 & 2 & 2 & 3 \\
\hline
\end{tabular}

Table 7: External door

\begin{tabular}{llllc}
\hline $\begin{array}{l}\text { Flush } \\
\text { plywood door }\end{array}$ & $\begin{array}{l}\text { Hard } \\
\text { wood door }\end{array}$ & $\begin{array}{l}\text { uPVC } \\
\text { door }\end{array}$ & $\begin{array}{l}\text { Folding } \\
\text { door(timber)(aluminum/timber) }\end{array}$ \\
\hline 1 & 3 & 3 & 1 & 2 \\
\hline
\end{tabular}

Table 8: Equipment

\begin{tabular}{|c|c|c|c|c|c|c|c|}
\hline \multicolumn{3}{|c|}{ Safety bar } & \multicolumn{2}{|c|}{ Insect net } & \multicolumn{3}{|c|}{ Door/Window equipment } \\
\hline $\begin{array}{l}\text { Mild } \\
\text { alloy/ }\end{array}$ & $\begin{array}{l}\text { Anodized } \\
\text { aluminum } \\
\text { chromium }\end{array}$ & & & mild & $\begin{array}{l}\text { Anod } \\
\text { alumi }\end{array}$ & & \\
\hline Steel & Grille & Metal & Plastic & steel & grille & Cooper & cover \\
\hline 1 & 3 & 1 & 3 & 1 & 3 & 3 & 2 \\
\hline
\end{tabular}

Table 9: Hand railing

\begin{tabular}{llll}
\hline Mild steel & $\begin{array}{l}\text { Timber } \\
\text { (nail or stainless }\end{array}$ & $\begin{array}{l}\text { Concrete } \\
\text { (reinforced) }\end{array}$ \\
\hdashline Hollow Section & Solid & steel screw or aluminum) & 3 \\
\hline 1 & 2 & 2 & 3 \\
\hline
\end{tabular}

- Avoid using thin red roofing tile due to exposure to strong coastal wind. Use heavier concrete roof tile instead

- If you need to use asbestos cement-corrugated roof sheet, ensure all nails been covered with bituminous compound

\section{Rain Water Downpipe (RWDP): Use uPVC types. Ceiling:}

- Avoid using timber ceiling slats or aluminum ceiling slats especially at the building external area where the installation material are made of steel. In unavoidable case, use rust-proof installation material type

- If using hanging ceiling, ensure hanging cable is made of G.I. with thick gauge and covered with plastic or m.s. solid rod

\section{Outside wall finishes:}

- If using brick wall with cement render, ensure the cement render have waterproof compound

- Use high quality wall finishes i.e. Shanghai Plaster or Boon Tile are encouraged and recommended

- Use wall finishes from tiles i.e. ceramic, porcelain, marble, granite or mosaic
- If using paint, use acrylic-emulsion-based textured finish paint

\section{Window:}

- If using adjustable glass ram window, get anodized aluminum jamb system with pivot and ellipse from nylon material

- If using sliding window, ensure rail material is from stainless steel or plastic material.

- If using casement window, window compartments must be used

\section{Door:}

- If plywood flat door being used, please ensure those plywood are made of marine ply

- Please use hard timber door panel for those expose to salty air

- $\quad$ uPVC door type can be used if appropriate to its function

\section{Fittings:}

- Avoid using m.s. safety bars and use anodized grille

- If using m.s. safety bar unavoidable, please ensure they are painted with anti-trust paint i.e., Micaccous Iron Oxide (MIO) or use a combination of organic or epoxy zinc-pigmented primers with top coats chlorinated rubber based, vinyl, epoxy or zinc richcoating

- Use insect net made of plastic

- All door/window fittings i.e., lockset, hinges, closers, screw and nail must be made from unrusty metal i.e., anodized aluminum, copper, stainless steel, zinc, brass or covered chromium, nickel, silver, brass or polymer

- Avoid using sink holder made of mild-steel with steel screw. Instead use reinforced concrete platform

Hand-railing: Avoid using hand railing and supporter from mild-steel especially using fixing plate embedded in concrete. Use hand rail made of reinforced concrete or hard wood instead. 
Am. J. Eng. \& Applied Sci., 4 (2): 307-313, 2011

Table 10: Fence/Gate

\begin{tabular}{lllll}
\hline Chain-link fencing & & & & \\
\hdashline G.I only & G.I with & Hard & Reinforced & Brick \\
& P.V.C coating & wood & concrete & block \\
\hline 1 & 1 & 2 & 2 & 3 \\
\hline
\end{tabular}

Table 11: Water tank

\begin{tabular}{llll}
\hline $\begin{array}{l}\text { Pressed } \\
\text { steel }\end{array}$ & $\begin{array}{l}\text { Polyethylene/ } \\
\text { HDPE }\end{array}$ & $\begin{array}{l}\text { Glass fiber } \\
\text { reinforced plastic } \\
\text { (hot pressed-GRP) }\end{array}$ & $\begin{array}{l}\text { Fiber glass } \\
\text { Reinforced polyester } \\
\text { (FRP) }\end{array}$ \\
\hline 1 & 3 & 3 & 3 \\
\hline
\end{tabular}

Table 12: Sewerage piping

\begin{tabular}{llll}
\hline Above ground & & \multicolumn{2}{l}{ Under ground } \\
\hline---- & -1 \\
Cast-Iron (C.I) & uPVC & uPVC & Vitrified clay \\
\hline 1 & 3 & 3 & 3 \\
\hline
\end{tabular}

Table 13: Wiring system

\begin{tabular}{lllllll}
\hline Item & \multicolumn{3}{l}{ Method/mat } & & & \\
\hline $\begin{array}{l}\text { Wiring } \\
\text { System }\end{array}$ & $\begin{array}{l}\text { Embedded } \\
\text { Conduit }\end{array}$ & 3 & Surface & 2 & & \\
$\begin{array}{l}\text { Surface } \\
\text { uPVC conduit }\end{array}$ & 3 & PVC casing & 2 & $\begin{array}{l}\text { Timber } \\
\text { batten }\end{array}$ & 2 \\
$\begin{array}{l}\text { Wiring } \\
\text { Support }\end{array}$ & Copper & 2 & $\begin{array}{l}\text { Stainless } \\
\text { steel }\end{array}$ & 3 & Mild steel & 1 \\
Screw & & & & &
\end{tabular}

Note: i: Usage of conduit uPVC only for building Not more than 4 storey heights; ii: G.I. Conduit must be used for much higher building

Table 14: Distribution board and main switch board

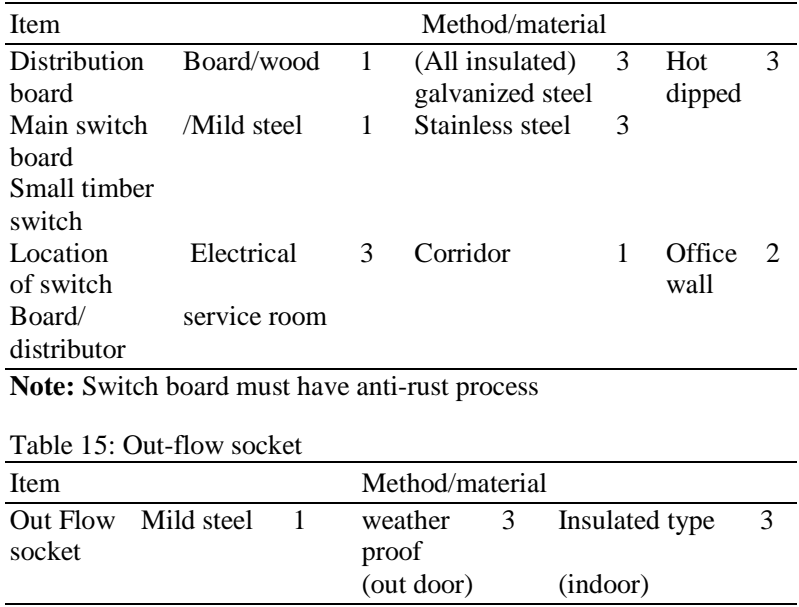

Table 16: Light switch

\begin{tabular}{lllll}
\hline Item & Method/material & & \\
\hline Light switch Mild steel 1 & $\begin{array}{l}\text { weather proof } \\
\text { (out door) }\end{array}$ & $\begin{array}{l}\text { Insulated type } \\
\text { (indoor) }\end{array}$ & 3 \\
\hline
\end{tabular}

Table 17: Electrical equipment inside the building

\begin{tabular}{|c|c|c|c|c|c|c|}
\hline Item & Method/materi & & & & & \\
\hline $\begin{array}{l}\text { Surface } \\
\text { pendant light }\end{array}$ & Bare channel & 1 & Anti corrosi & & $\begin{array}{l}\text { with prismatic/ } \\
\text { diacon diffuser }\end{array}$ & \\
\hline Ceiling fan & Stainless steel & 3 & Aluminum & 3 & Timber & 2 \\
\hline Exhaust Fan & Stainless steel & 3 & Plastic & 3 & Mild steel & 1 \\
\hline
\end{tabular}

\section{Fence/ fence gate:}

- Avoid using G.I. chain link fence; instead use sand brick block, reinforced concrete or hard wood

- If using G.I. chain link fence unavoidable, ensure it has been painted.

- For concrete fence column, ensure to have the mix of $1 \frac{1}{2}: 3$ and not 1: 4 as usual. Ensure the reinforced concrete cover had enough thickness.

\section{Water tank:}

- Avoid using pressed steel water tank especially when it is directly expose to salty wind. Use water tank made of glass fiber reinforced plastic hot pressed (GRP) or polyethylene/HDPE

- If using pressed steel water tank unavoidable, make sure it is paint with paint type as specified and the location must be not directly expose to the sea wind

\section{Sewerage piping:}

- Avoid using sewerage pipe made of cast iron. Use uPVC type where for on ground; use C Class and for underground; choose D class type

- Vitrified Clay pipe can be used for underground work only

\section{Electrical equipment: Wiring system:}

- All surface wiring must use uPVC conduit (unplasticised PVC) and cable system $\mathrm{PVC} / \mathrm{PVC}$ within PVC casing or PVC/PVC on top of timber batten

- Distribution within metal trunking casing must use uPVC casing type

- All screws using to support conduit, casing, PVC casing or timber batten must be from copper type

\section{Distribution board and main switch board:}

- Use distribution board with fully insulated which made from material i.e., uPVC, fiber glass, Bakelite

- Main switch board and distribution board must go through anti-trust process as below

"All metal clad switchboards and distribution boards shall be fabricated from galvanized sheet metal of thickness not less than $2.0 \mathrm{~mm}$ using brass screw and nut". 


\section{Switch and socket out flow:}

- Use switch and out flow socket with anti-trust (scaled type) or anti-corrosive for all surface fittings

- Light switch box and out flow switch (switch and socket boxes) for embedded wiring must be from uPVC type and not from metal type

Electrical equipment inside the building: All pendant light install within the open area i.e. roofed hallway or corridor and also inside the building (non-airconditioned area) must be made from anti-trust type according to the protected grade IP55.

All pendants light including hanging type other than from anti-trust light type must have anti-trust process as per below; before installation:

- The casing of all fluorescent other than anticorrosive type shall be made of hot-dipped galvanized sheet steel.

- It shall be undercoated with zinc-rich primer and finished with two (2) coatings of stove while baked acrylic enamel paint

- All necessary screws required shall be made of brass.

The metal part of the light must be painted with anti-rust paint every year.

Ceiling fan: Fan blade must be made of stainless steel or aluminum.

\section{Compound lighting:}

- Lamp post must make of hot-dipped galvanized type or tantalized wooden pole or reinforcedconcrete post with concrete cover with right thickness

- For compound lighting must be from anti-rust type and all supporting equipments i.e. stirrup, head frames must be of anti-rust i.e., copper screw, stirrup aluminum and head frames hot dipped galvanized

- Light bowl must be from pressure die cast aluminum and of anodized aluminum reflectors and also having injection molded stabilized acrylic vandal resistant cover bowl

\section{Mechanical equipment:}

Conduits: All G.I. conduits must be painted with redoxide base paint and with enamel finishes paint to resist rust.
Pipe Hangers, M.S. Strips and M.S. Angels:

- Must be painted with red-oxide primer base paint or zinc chromate primer and chlorinated rubber base paint finishes, vinyl base, epoxy base or zincrich coating

- Must be painted with enamel and dried with oven baked enamel paint

Valve in the pump room: Use valve made of brass or having aluminum body.

Hose reel box (Cabinet): Cabinet must be made of non-metal material i.e. timber, plywood, gypsum board. If you need to use metal; use aluminum.

\section{Air-conditioned Outside skin (Window Type):}

- Use aluminum for casing and grilles

- Outside skin can be made of galvanized iron with anti-rust base paint and dried with oven baked enamel paint

- For casing standard, use red-oxide base paint or zinc chromate primer and finishes type of chlorinated rubber base, vinyl base, epoxy base or zinc-rich coating

G.I Supply and return air grilles (for airconditioner):

- All G.I. supply and return air grilles must be painted with enamel paint and dried with oven baked enamel paint

- Supply and return air grilles must be made from aluminum and anodized according to preferred color

\section{Motorized control valves:}

- Material for linkage mechanism must be those nonmetal type i.e. ABS, UHPVC, FRP

- If using metal unavoidable, use those type i.e., mild- steel (brass or aluminum)

Chrome plated sprinkler head: Use material not from metal i.e., UHPVC, FRP instead.

\section{Exhaust fan:}

- Use low-pressure exhaust fan's blade made of plastic

- For high pressure exhaust fan's made of steel; blade and grille must be painted as below:

- Base paint with red oxide primer or zinc chromate primer 
Am. J. Eng. \& Applied Sci., 4 (2): 307-313, 2011

Table 18: Compound lighting

\begin{tabular}{|c|c|c|c|c|c|c|}
\hline Item & & & Method/material & & & \\
\hline Compound lighting & Pressure die cast aluminum & 2 & Plastic & 1 & Vandal resistant acrylic bowl & 3 \\
\hline Lamp post & Hot dipped galvanized steel & 3 & Tantalized hard wood & 2 & Aluminum & 3 \\
\hline Support Equipment & & & Hot dipped galvanized head frame & 3 & Aluminum stirrup & 2 \\
\hline
\end{tabular}

Table 19: Mechanical equipment

\begin{tabular}{|c|c|c|c|c|c|c|c|c|c|c|c|c|c|c|}
\hline & Nil & A & $\mathrm{B}$ & $\mathrm{C}$ & $\mathrm{D}$ & $\mathrm{E}$ & $\mathrm{F}$ & $\mathrm{CI}$ & MS & GI & $\mathrm{Br}$ & $\mathrm{Al}$ & NM & $\mathrm{P}$ \\
\hline G.I conduits & 1 & 2 & 3 & & & & & & & 1 & & & & \\
\hline M.S strips and angles & & & & 3 & 3 & 3 & 3 & & 1 & & & & & \\
\hline Valves body & & & & & & & & 1 & 1 & 1 & 3 & 3 & & \\
\hline Hose reel box & & & 3 & 3 & 3 & 3 & 3 & & 1 & 2 & & 3 & 3 & \\
\hline Air-condoner chassis & & 2 & 3 & 3 & 3 & 3 & 3 & & 1 & 2 & & 3 & & \\
\hline Air-condoner grilles & 1 & 2 & 3 & & & & & & 1 & & & 3 & & \\
\hline Motorized valve & & & & & & & & & 1 & 2 & 3 & 3 & & 3 \\
\hline Sprinkler's ceiling rose & & & & & & & & & 1 & & & 3 & & \\
\hline Exhaust fan blade & & & 3 & 3 & 3 & 3 & 3 & & 1 & 2 & & 3 & & 3 \\
\hline
\end{tabular}

Treatment: A: Red Oxide; B: Red Oxide + enamel; C: Red Oxide + rubber base; D: Red Oxide + vinyl base; E: Red Oxide + epoxy base; F: Red Oxide + zinc rich; Material: CI: Cast Iron; MS: Mild Steel; GI: Galvanized Iron; Br: Brass; Al: Aluminum; NM: Non-Metal; P: Plastic

- Paint second layer with chlorinated rubber base, vinyl base or epoxy base

- $\quad$ Finishes paint layer with abrasive resistant paint

Useable construction material chart: The following charts are the summary from above tables. Priority usage is as follow:

- Not suitable

- Suitable

- Very suitable

\section{Construction material (Building):}

Note: External and Internal Ceiling:

- All nails and screws are from stainless steel, zinc, aluminum, copper or brass.

- Internal ceiling

- Non air-conditioned

- (Ceiling hangers are made of m.s. rod not G.I. wire)

- Air-Conditioned

- (Ceiling hangers are made of m.s. rod not G.I. wire)

\section{CONCLUSION}

This initial guideline is an important task in preparing much more complete guide. Further research and study can be done in order to produce more comprehensive guide to be used by all parties involve. As we may aware, in coastal areas, a building can be considered a success only if it is capable of resisting damage from coastal hazards and coastal processes over a period of decades.

We hope the use this guideline will at least help those involved in constructing the structure along the coastal area particularly in this tropical region of
Peninsular Malaysia. We assume by having proper coastal building guideline may create more positive awareness in constructing better management coastal buildings and can save time and money to maintain the said structures.

In future; to improve coastal construction practices, one to consider contacting local building official to obtain the latest applicable building code requirements for coastal construction. We hope the Government and communities may have to enforce regulatory requirements that determine where and how these buildings may be sited, designed and constructed.

\section{ACKNOWLEDGEMENT}

We extend our gratitude to the Public Works Department Headquarters: Building Division, Electrical Division and Mechanical Division for facilitating the field equipments. Specials thanks are also who rendered their timely help to the successful completion of this project research.

\section{REFERENCES}

Ahmad, F., A.S. Yahaya and M.A. Farooqi, 2006. Characterization and geotechnical properties of penang residual soils with emphasis on landslides. Am. J. Environ. Sci., 2: 121-128. DOI: 10.3844/ajessp.2006.121.128

Economou, A., 2009. The land uses' consequences in coastal area of faliraki and delta penaeus river in Greece. Am. J. Agric. Biol. Sci., 4: 39-48.

Ekphisutsuntorn, P., P. Wongwises, J. Zhu and S. Vongvisessomjai, 2010. Impacts of typhoon on wave height at bangkhuntien shoreline. Am. J. Environ. Sc., 6: 308-315. DOI: 10.3844/ajessp.2010.308.315 